Note

\title{
Qualitative characteristics of meat from confined crossbred heifers fed with lipid sources
}

\author{
Giovani Fiorentini ${ }^{1}$, Telma Teresinha Berchielli1,3* , Márcia Cristina Araújo Santana1, ${ }^{1, \pi}$, Paulo Henrique Moura Dian ${ }^{1, \S}$, Ricardo \\ Andrade Reis ${ }^{1,3}$, Alexandre Amstalden Moraes Sampaio ${ }^{1,3}$, Marcos Vinicius Biehl2
}

IUNESP/FCAV - Depto. de Zootecnia, Via de Acesso Prof. Paulo Donatto Castellane, s/n - 14884-900 - Jaboticabal, $\mathrm{SP}$ - Brasil.

2USP/ESALQ - Depto. de Zootecnia, C.P. 09 - 13418-900 Piracicaba, SP - Brasil.

${ }^{3}$ INCT/CA - UFV - Depto. de Zootecnia, Av. Peter Henry Rolfs, s/n - Campus Universitário - 36570-000 - Viçosa, MG - Brasil. ${ }^{*}$ Corresponding author <ttberchi@fcav.unesp.br>

Edited by: Gerson Barreto Mourão

Received September 10, 2010

Accepted March 01, 2012

\begin{abstract}
Lipids have been used in ruminant feed to replace high amounts of grain for increasing the diet energy density, performance and meat quality. This study evaluated the qualitative characteristics of meat from feedlot heifers fed with sources of lipid supplements. Twenty-one crossbred heifers $(1 / 4$ Nelore $\times 1 / 4$ Santa Gertrudis $\times 1 / 2$ Braunvieh) were used. Each heifer received $60 \%$ forage with a base of corn silage and $40 \%$ concentrate, resulting in $5.8 \%$ lipid content in the total diet. The following sources of lipids were used: soybeans, protected fat and soybean oil. There were no differences on physical characteristics of meat samples from heifers fed with the lipid sources. Soybeans increased the concentration of linoleic acid, content of polyunsaturated fatty acid and activity of the $\Delta^{9}$-desaturase $\mathrm{C} 16$ enzyme in the Longissimus muscle. The use of soybean oil in the diet increased the oleic acid, monounsaturated fatty acid, total cis- and trans-fatty acids (C18:0) and the activity of the $\Delta^{9}$-desaturase $\mathrm{C} 16$ enzyme in the subcutaneous fat. Diets with soybean grain had greater deposition of linoleic and linolenic acids than diets with fat protected and greater presence of these essential fatty acids are associated to a better composition and meat quality.

Keywords: meat quality, protected fats, soybeans, soybean oil
\end{abstract}

\section{Introduction}

Beef is a food high in protein and is one of the main nutrient sources for humans, since it consists of edible muscle, connective tissue and associated fat. The most important meat quality attributes include tenderness, taste, juiciness, leanness, nutrient quantities, safety and convenience (Webb, 2006). However, there is great variation in the chemical and physical components of beef, which can be attributed to factors such as the breed, sex, and age of the animals, nutrition and anatomical position of the cut (Rotta et al., 2009b). The evaluation of the meat quality by consumers begins with the colour of meat and quantity of fat coverage, followed by processing aspects, such as fluid loss during thawing and cooking, and tenderness, which is considered the most important qualitative aspect of beef (Koohmaraie et al., 2002). Currently, there is a concern with human nutrition with the sanitary quality of food and, more importantly, the possible effects (harmful or beneficial) of certain foods or nutrients on consumer health (Kazama et al., 2008).

The beef consumption has been mentioned as one of the main factors that can lead to the development of cardiovascular diseases, obesity, hypertension and cancer. These effects are directly related to the fat present in beef, which has an elevated concentration of saturated

sPresent address: Universidade Camilo Castelo Branco, R. Hilário da Silva Passos, 950, Rural - Campus Descalvado - 13690-970 - Descalvado, SP - Brasil.

TPresent address: Universidade Federal da Bahia/Escola de Medicina Veterinária e Zootecnia, Av. Adhemar de Barros, 500 - 40170-110 Salvador, BA - Brasil. fatty acids (SFAs) and a lower ratio of polyunsaturated to saturated fats when compared to the fat of monogastric animals, that difference is due mainly to the process biohydrogenation that occurs in the rumen by the action of different microorganisms (French et al., 2000).

There has been a growing interest in recent years for the development of nutritional strategies for manipulation of the fatty acid composition in beef (Wood et al., 2003). This interest may be motivated by the need to produce a healthier meat, reducing its implication in diseases associated with modern life and improving its competitiveness with pork and poultry. Accordingly, this study aimed to evaluate the qualitative characteristics of the meat from crossbred heifers fed with different lipid sources.

\section{Materials and Methods}

\section{Animal management and experimental design}

This study was carried out at Jaboticabal, state of São Paulo, southeast Brazil $\left(21^{\circ} 15^{\prime} 22^{\prime \prime} \mathrm{S}, 48^{\circ} 18^{\prime} 58^{\prime \prime} \mathrm{W}\right.$, $595 \mathrm{~m}$ altitude). The climate, according to Köppen type AWa is characterized as subtropical dry winter short, moderate and dry (Apr. to Sep.) and hot and rainy summer (Oct. to Mar.). The experimental area has 24 individual pens with cement floors, partial coverings, drinking fountains and troughs for forage and concentrate. Twenty-one crossbred heifers (1/4Nelore $\times 1 / 4$ Santa Gertrudis $\times 1 / 2$ Braunvieh) with an approximate age of $14 \pm$ 3 months were used in this study. The heifers had been part of an experiment in which they received mineral supplementation and/or protein and energy supplementation $(0.3 \%$ the body weight) in the rainy period. They had an average and standard deviation body weight of 
$300 \pm 14.8 \mathrm{~kg}$, forming a homogenous group. For an initial $25 \mathrm{~d}$ period, the animals were adapted to the facilities, management and diet intake. After this period, they were randomly placed in individual pens.

The experimental diets were formulated to provide an intake of the dry matter at $2.32 \%$ of live weight and average daily gain of $1.19 \mathrm{~kg}$. The formulations were obtained by the RLM ${ }^{\circledR} /$ ESALQ-USP software (Lanna et al., 1999) in accordance with the Cornell Net Carbohydrate and Protein System (CNCPS) that was developed by Fox et al. (1992). The diets were isocaloric and isonitrogenous and were composed of corn silage as roughage $(60 \%)$ and corn and soybean meal as concentrate mixture $(40 \%)$. The diets were also complemented by a mineral mixture (Table 1). In the soybean diet, the soybeans were the main protein source.

The ingredients were ground in a hammer mill fitted with a sieve with holes of $5 \mathrm{~mm}$ in diameter. The proportion of the ingredients in the diets the composition of the foods and composition of the fatty acids are found in Tables 1 and 2, respectively.

The roughage (corn silage) was provided with the experimental concentrates to the animals once a day at 8h00. During the entire experimental period, the quantities provided were adjusted to allow close to a $10 \%$ surplus in relation to the total consumed the day before, subsidizing a consumption known as "ad libitum".

Table 1 - Ingredients and composition of the diet.

\begin{tabular}{|c|c|c|c|}
\hline \multirow{2}{*}{ Ingredient (\% DM) } & \multicolumn{3}{|c|}{$\operatorname{Diet}^{A} \%$ of DM } \\
\hline & SB & $\mathrm{PF}$ & SO \\
\hline Corn silage & 60.00 & 60.00 & 60.00 \\
\hline Protected fat & 0.00 & 3.20 & 0.00 \\
\hline Soy grain & 14.00 & 0.00 & 0.00 \\
\hline Soybean meal & 0.00 & 12.80 & 12.40 \\
\hline Soybean oil & 0.00 & 0.00 & 2.60 \\
\hline Ground corn & 24.00 & 22.00 & 23.00 \\
\hline Mineral salt ${ }^{\mathrm{B}}$ & 2.00 & 2.00 & 2.00 \\
\hline \multicolumn{4}{|l|}{ Composition } \\
\hline \multirow[t]{2}{*}{ Dry matter (DM) (\%) } & 56.1 & 56.1 & 55.7 \\
\hline & \multicolumn{3}{|c|}{$\%$ DM } \\
\hline Organic matter & 94.90 & 94.10 & 94.80 \\
\hline Ash & 5.10 & 5.90 & 5.20 \\
\hline Crude protein & 13.20 & 13.60 & 13.50 \\
\hline Ether extract & 5.80 & 5.80 & 5.80 \\
\hline Neutral detergent fiber & 40.40 & 39.70 & 39.60 \\
\hline Acid detergent fiber & 20.30 & 20.00 & 20.00 \\
\hline Lignin & 4.50 & 4.40 & 4.90 \\
\hline \multirow[t]{2}{*}{ Total carbohydrates } & 75.90 & 74.60 & 75.50 \\
\hline & \multicolumn{3}{|c|}{$\mathrm{kcal} \mathrm{g}^{-1} \mathrm{DM}$} \\
\hline Crude energy & 4.60 & 4.60 & 4.70 \\
\hline
\end{tabular}

ASB - diet containing $60 \%$ corn silage and $40 \%$ concentrate with a base of soybeans as the lipid source; PF - diet containing $60 \%$ corn silage and $40 \%$ concentrate with a base of protected fat as the lipid source; SO - diet containing $60 \%$ corn silage and $40 \%$ concentrate with a base of soy oil as the lipid source; ${ }^{B}$ Composition of mineral salt: (Ca: 45 g; P: 12 g; Mg: 46 g; S: 14 g; Na: 58 g; Cu: 140 mg; Mn: 410 mg; Zn: 525 mg; I: 10 mg; Co: 8 mg; Se: $2.5 \mathrm{mg}$; F (Maximum): $120 \mathrm{mg}$.
After the end of the experimental period, the samples were thawed and grouped by animal and by time period. Next, they were freeze-dried, ground in a $1-\mathrm{mm}$ mesh sieve and analysed to determine the content of dry matter $(\mathrm{DM})$, organic matter $(\mathrm{OM})$, ether extract (EE) and crude protein $(\mathrm{CP})$, according with Association Official Analytical Chemists (AOAC, 1990). They were also analysed to determine the neutral detergent fibre (NDF) and acid detergent fibre (ADF) according to the method of Van Soest et al. (1991) (Table 1).

Slaughter, sample collection and meat quality grades After 68 days in feed-lot the animals were transported to a commercial abattoir. The next day, after not eating solids for $28 \mathrm{~h}$, the slaughter took place. This was carried out by a concussion stunning procedure using a compressed air pistol and subsequent bleeding by cutting the jugular veins and carotid arteries. The study was approved by the Ethics and Animal Welfare Committee (CEBEA) at the Universidade Estadual de São Paulo (UNESP), Jaboticabal campus.

The carcass remained for $24 \mathrm{~h}$ in cold chamber and after this period was obtained meat sampling (sirloin), a perpendicular cut was made in the Longissimus muscle between the $12^{\text {th }}$ and $13^{\text {th }}$ ribs. Four samples of $2.5-\mathrm{cm}$ thick sirloin were removed at the $12^{\text {th }}$ rib and were vacuum packed and cooled to be analysed the next day ( 48 hours after slaughter) for their qualitative characteristics.

For the determination of the meat colour, a Minolta Chroma Meter CR-300 colorimeter was used to measure the $\mathrm{L}^{*} \mathrm{a}^{*} \mathrm{~b}^{*}$ space. In this space, $\mathrm{L}^{*}$ indicates luminosity, and $\mathrm{a}^{*}$ and $\mathrm{b}^{*}$ are the chromaticity coordinates as follows: the axis that runs from $-\mathrm{a}^{*}$ to $+\mathrm{a}^{*}$ varies from green to red, and the axis that runs from $-b^{*}$ to $+b^{*}$ varies between blue and yellow. Thirty minutes before performing the readings at different positions on the meat, a transversal cut was made to the muscle to expose the myoglobin to oxygen (Abularach et al., 1998).

Table 2 - Composition of fatty acids for corn silage and for the experimental concentrates containing different lipid sources.

\begin{tabular}{|c|c|c|c|c|}
\hline \multirow{2}{*}{ Fatty acid } & \multirow{2}{*}{ Corn silage } & \multicolumn{3}{|c|}{ Concentrate $^{A}$} \\
\hline & & SB & PF & SO \\
\hline & & & & \\
\hline C10: 0 (capric) & 0.01 & 0.04 & 0.04 & 0.04 \\
\hline C12: 0 (lauric) & 0.42 & 0.03 & 0.46 & 0.06 \\
\hline C14: 0 (myristic) & 0.55 & 0.16 & 0.30 & 0.90 \\
\hline C15: 0 (pentatonic) & 0.05 & 0.00 & 0.04 & 0.14 \\
\hline C16: 0 (palmitic) & 19.10 & 19.70 & 18.40 & 21.90 \\
\hline C16: 1 C9 (palmitoleic) & 0.18 & 0.27 & 0.13 & 0.26 \\
\hline C17: 0 (daisy) & 0.25 & 0.24 & 0.34 & 2.06 \\
\hline C18: 0 (stearic) & 0.00 & 10.70 & 5.29 & 7.50 \\
\hline C18: 1 C9 (oleic) & 25.60 & 27.80 & 21.30 & 28.50 \\
\hline 18:2 C9 C12 (linoleic) & 40.30 & 31.00 & 42.80 & 23.80 \\
\hline 18:3 n3 (linolenic) & 4.22 & 1.20 & 2.94 & 0.76 \\
\hline
\end{tabular}


The $\mathrm{pH}$ was measured in the muscle portion of the sampled sirloin $48 \mathrm{~h}$ after slaughter with a Jonhis digital meter (IpHPJ model). The water retention capacity was obtained by the difference between the weights of a meat sample (approximately $2 \mathrm{~g}$ ) before and after being subjected to a $10 \mathrm{~kg}$ pressure for $5 \mathrm{~min}$ (Hamm, 1960).

To calculate the loss of water by cooking, the pieces of beef were baked in an industrial electric oven at a temperature of $175{ }^{\circ} \mathrm{C}$ until reaching a temperature of $70{ }^{\circ} \mathrm{C}$ in their geometric centre (Abularach et al., 1998). The weights of the meat samples before and after cooking were used for the calculations of total losses. After cooling the baked samples, four cylinders were removed from the meat with a leaker to determine the force needed to transversally cut each cylinder using a Texture Analyser instrument (TA-XT2i) attached to a Warner Bratzler blade. The average force of the four cylinders was calculated to represent the texture or shear force of each piece of beef (Abularach et al., 1998).

For the sensory analysis, the meat samples were baked in an electric oven at a temperature of $175^{\circ} \mathrm{C}$ until reaching $75{ }^{\circ} \mathrm{C}$ in their geometric centres, and after cooling, they were cut and offered to 30 panellists. In this test, the attributes of flavour, texture, preference and general appearance were evaluated. The scores varied from one to nine with one being maximal disapproval and nine being maximal approval (Meilgaard et al., 1999).

For the determination of the fatty acid profile in the meat and subcutaneous fat, a sample of sirloin from each animal (between the $12^{\text {th }}$ and $13^{\text {th }}$ rib) was used to perform the lipid extraction, transesterification of fatty acids and methylation of fatty acids in the muscle and subcutaneous fat. The extraction and evaluation of the total lipids of the samples were performed according to the modified methodology of Hara and Radin (1978), which utilised nearly $1.5 \mathrm{~g}$ of the subcutaneous fat and $3.0 \mathrm{~g}$ of the Longissimus muscle samples for the extraction of fat with the use of hexane/isopropanol $\left(3: 2 \mathrm{v} \mathrm{v}^{-1}\right)$.

For the transesterification of the fatty acids, the methodology described by Christie (1982) was used with modifications using a methanolic solution of sodium methoxide. The fatty acid methyl esters were separated in a $100 \mathrm{~m}$ capillary column with silica (SP-2560) fused with hydrogen as the carrier gas $\left(1.8 \mathrm{~mL} \mathrm{~min}^{-1}\right)$ and a flame ionisation detector (FID). Each sample was rotated as described by Griinari et al. (1998), with a temperature gradient of $70{ }^{\circ} \mathrm{C}$ to $240{ }^{\circ} \mathrm{C}$ for the identification of fatty acid peaks. After the identification of the peaks, a standard butter (CRM 164; Commission of the European Communities, Community Bureau of Reference, Brussels, Belgium) was used for the certification of the recuperation of the fatty acids according to the peaks and retention times.

The activity indices of the $\mathrm{C} 16$ and $\mathrm{C} 18 \Delta^{9}$ desaturase enzymes were also calculated. These enzymes are responsible for the conversion of fatty acids saturated with $\mathrm{C} 16$ and $\mathrm{C} 18$ atoms, respectively, into their corresponding monounsaturated carbons with double bonds on C9, as described by Malau-Aduli et al. (1997). This index expresses the quantity of the product (monounsaturated fatty acid) as a percentage of the substrate available for the conversion. These indexes were obtained by the following equations: $\Delta^{9}$ - Desaturase (16) - index of $\mathrm{C} 16$ desaturase enzyme activity $=100(16: 1 /$ $16: 0+16: 1)$ and $\Delta^{9}$ - Desaturase (18) - index of C18 desaturase enzyme activity $=100(18: 1 / 18: 0+18: 1)$.

\section{Statistical analysis}

The experimental design used for the data analysis was completely randomised with three treatments and seven replicates with a total of 21 animals. The averages were compared with a Tukey's test $(p<0.05)$. The statistical analyses were performed by the PROC GLM software of SAS (1997). For the qualitative characteristics of the meat (flavour, texture, appearance and general aspect), was used the non-parametric Kruskal-Wallis test (procedure NPAR 1 WAY from SAS (1997).

\section{Results and Discussion}

The shear force did not vary with the lipid supplementations (Table 3). In the study by Restle et al. (2001), the average value obtained for shear force was $6.24 \mathrm{~kg} \mathrm{~cm}^{-2}$ in feedlot finished heifers that were $3 / 4$ Cha-

Table 3 - Shear force (SF), losses from cooking (LFC), water retention capacity (WRC), pH and characteristics of sirloin meat from feedlot crossbred heifers receiving different lipid sources.

\begin{tabular}{|c|c|c|c|c|c|c|}
\hline \multirow{2}{*}{ Characteristic } & \multicolumn{3}{|c|}{$\operatorname{Diet}^{A}$} & \multirow{2}{*}{$\mathrm{SEM}^{\mathrm{B}}$} & \multirow{2}{*}{$P$ value } & \multirow{2}{*}{$\mathrm{CV}^{\mathrm{C}}$} \\
\hline & SB & $\mathrm{PF}$ & SO & & & \\
\hline $\mathrm{SF}\left(\mathrm{kg} \mathrm{cm}^{-2}\right)$ & 7.48 & 7.68 & 7.76 & 0.21 & 0.87 & 13.40 \\
\hline LFC (\%) & 26.90 & 27.90 & 27.70 & 0.76 & 0.86 & 13.20 \\
\hline WRC (\%) & 74.80 & 75.20 & 73.10 & 0.56 & 0.26 & 3.35 \\
\hline $\mathrm{pH} 48 \mathrm{~h}$ after slaughter & 5.96 & 5.92 & 5.89 & 0.01 & 0.06 & 0.79 \\
\hline$L^{*}$ (luminosity) & 36.00 & 36.90 & 36.90 & 0.34 & 0.49 & 4.36 \\
\hline$a^{*}$ (intensity of the colour red) & 15.20 & 15.80 & 15.70 & 0.21 & 0.47 & 6.12 \\
\hline $\mathrm{b}^{*}$ (intensity of the colour yellow) & 3.07 & 3.01 & 2.75 & 0.20 & 0.80 & 32.02 \\
\hline
\end{tabular}

ASB - diet containing $60 \%$ corn silage and $40 \%$ concentrate with a base of soybeans as the lipid source; PF - diet containing $60 \%$ corn silage and $40 \%$ concentrate with a base of protected fat as the lipid source; SO - diet containing $60 \%$ corn silage and $40 \%$ concentrate with a base of soy oil as the lipid source; ${ }^{B}$ SEM - standard error of mean; ${ }^{\mathrm{C}} \mathrm{CV}$ - coefficient variation (\%). 
rolais and $1 / 4$ Nellore, which was a lower value than the value in this study $\left(7.64 \mathrm{~kg} \mathrm{~cm}^{-2}\right)$. According to Lawrie (2005), values above $5.00 \mathrm{~kg} \mathrm{~cm}^{-2}$ characterise the meat as hard.

The SMS Warner-Bratzler cell blade used in this study had a thickness of $3 \mathrm{~mm}$, whereas the thickness of the standard Warner-Bratzler (WB) blade is $1.016 \mathrm{~mm}$ (0.04 inches). The greater thickness of the blade may influence the value of the maximal shear force as reported by Silva et al. (1999). They reported a greater sensitivity of the standard Warner-Bratzler blade to detect the differences in the texture of the meat.

Several factors may influence the tenderness of meat, such as the degree of marbling (or intramuscular fat), intermuscular fat, age, muscle glycogen reserves, rigor mortis, $\mathrm{pH}$ and species pattern. The greater shear force values this study $\left(7.64 \mathrm{~kg} \mathrm{~cm}^{-2}\right)$ could be attributed to other factors, such as age or difference in enzyme activity, that appear to be influenced by the breed composition of the animals. In a study with crossbred Angus and Brahman animals, Stolowski et al. (2006) found that the breed type influences the tenderness due to the muscular difference linked to maturation rate and calpastatin activity.

The variables related to the total losses, such as losses by dripping, losses by evaporation and losses by water retention, did not differ $(p>0.05)$ with average value $74.3 \%$, but the observed values remained at appropriate levels. The loss by cooking was not influenced by the sources of lipids with average value of loss of $27.5 \%$.

Differences were not observed $(p>0.05)$ in the average $\mathrm{pH}$ values $48 \mathrm{~h}$ after slaughter with the average $\mathrm{pH}$ value of 5.92, which was close to the recommended limit ( $\mathrm{pH}$ 6.0). According to Fernandes et al. (2008), pH 6.0 is considered as a dividing point between a normal cut and a dark cut of meat. In Brazil, the slaughterhouses only export meat that has $\mathrm{pH}$ value less than 5.80 that is directly measured in the Longissimus muscle $24 \mathrm{~h}$ postmortem (Oliveira et al., 2009), because the meat may be dark when the $\mathrm{pH}$ is above 6.0 due to the higher enzymatic activity, greater water retention and lesser oxygen penetration.

The analysis of meat colour demonstrated average values of $36.6,15.6$ and 2.94 for $\mathrm{L}^{*}, \mathrm{~b}^{*}$ and $\mathrm{a}^{*}$, respectively, and differences were not observed $(p>0.05)$ (Table 3). The results are similar to those described by Fernandes et al. (2008). They reported the following re- sults for Canchim females: $37.39\left(\mathrm{~L}^{*}\right), 15.92\left(\mathrm{~b}^{*}\right)$ and $2.97\left(\mathrm{a}^{*}\right)$. They also stated that the luminosity and colouration of the meat are directly related to the $\mathrm{pH}$ value after cooling. In this study, $\mathrm{pH}$ values remained within the ideal limits, and the $\mathrm{L}^{*}, \mathrm{a}^{*}$ and $\mathrm{b}^{*}$ characteristics presented values that are considered normal.

The analysis of the sensory panel did not show differences in the flavour, yet for the texture and overall acceptance, there was an effect on the results from the diets (Table 4). When the texture characteristic of the meat was considered by the sensory panel, the meat from the animals that received protected fat and soybean oil had a better classification $(p \leq 0.05)$ compared to the meat from animals that received soybeans.

The texture results obtained from the sensory panel (Table 4) did not correlate with the results from the analysis performed by the texturometer (shear force) (Table 3). The basis of the mechanical methods for evaluation is the cut force, which is an objective measure (Lawrie, 2005). The impression of texture in the sensory evaluation involves the ease of teeth penetration into the meat, disintegration of the meat in the mouth and quantity of residue after chewing, which makes this analysis more complex and makes it difficult to find a correlation among the evaluations.

The texture result may be related to the fat coverage of carcasses because animals fed with protected fat had a greater proportion of adipose tissue in the carcass. The fat coverage has the important function of protecting the carcass from the low temperatures observed in refrigeration chambers (Pereira et al., 2000). Therefore, thicker layers of fat are more effective as thermal insulators because they minimise the shortening of muscle fibres caused by the abrupt fall in temperature on the surface of the muscle. However, this has negative consequences for the tenderness and texture of the meat.

There was difference $(p \leq 0.05)$ in the concentration of linoleic acid (18:2 C9 C12), linolenic acid (18:3 n3), PUFA content and PUFA ratio, which is the ratio of SFAs. Animals fed with soybeans had a greater concentration $(p \leq 0.05)$ of linoleic acid (18:2 C9 C12), linolenic acid (18:3 n3), PUFA content and PUFA ratio, which is the ratio of SFAs in the Longissimus muscle when compared with animals fed with protected fat 13.84 versus $2.33 ; 0.21$ versus $0.12 ; 5.61$ versus 3.36 and 0.12 versus 0.07 , respectively). The concentration of the linoleic and linolenic fatty acids PUFA content and PUFA ratio from the diet with soybean oil did not differ from the other di-

Table 4 - Sensory analysis completed by a gourmet panel of the meat from crossbred heifers finished in confinement receiving lipid sources.

\begin{tabular}{|c|c|c|c|c|c|c|}
\hline \multirow{2}{*}{ Sensory characteristics } & \multicolumn{3}{|c|}{$\operatorname{Diet}^{A}$} & \multirow{2}{*}{ SEM $^{B}$} & \multirow{2}{*}{$P$ value } & \multirow{2}{*}{$\mathrm{CV}^{\mathrm{C}}$} \\
\hline & SB & $\mathrm{PF}$ & so & & & \\
\hline Overall acceptance & $6.12^{b}$ & $7.33^{\mathrm{a}}$ & $6.54^{\mathrm{ab}}$ & 0.32 & 0.04 & 23.5 \\
\hline Flavour & 7.04 & 7.42 & 6.58 & 0.31 & 0.56 & 21.9 \\
\hline Texture & $5.50^{\mathrm{b}}$ & $7.29^{a}$ & $6.71^{\mathrm{a}}$ & 0.34 & 0.04 & 25.8 \\
\hline
\end{tabular}

ASB - diet containing $60 \%$ corn silage and $40 \%$ concentrate with a base of soybeans as the lipid source; PF - diet containing $60 \%$ corn silage and $40 \%$ concentrate with a base of protected fat as the lipid source; SO - diet containing $60 \%$ corn silage and $40 \%$ concentrate with a base of soy oil as the lipid source; ${ }^{B}$ SEM - standard error of mean; ' $\mathrm{CV}$ - coefficient of variation (\%); a,bAverages followed by different lower case letters, in the same line, differ (Kruskal-Wallis, $p<0.05$ ). 
ets. The index of the $\mathrm{C} 16 \Delta^{9}$-desaturase enzyme also was a difference $(p \leq 0.05)$ animals fed with soybeans oil had a greater concentration when compared with animals fed with protected fat (12.9 versus 11.0$)$ and soybean did not differ from the other diets.

The other fatty acids and the total content of SFAs, MUFAs, unsaturated fatty acids (UFAs), total cis-fatty acids (C18:0) and total trans-fatty acids (C18:0) were not affected $(p>0.05)$ by the lipid sources. Furthermore, the index of the $\mathrm{C} 18 \Delta^{9}$-desaturase enzyme and the ratio of UFAs to SFAs were not affected $(p>0.05)$ by the lipid sources (Table 5).

According to Scollan et al. (2006), the predominant SFAs in beef are C14:0, C16:0 and C18:0, with C18:0 representing approximately $30 \%$ of the total of SFAs. Among these, the myristic acids (C14:0) and palmitic acids (C16:0) are the fatty acids that deserve the most attention for being considered as hypercholesterolemic (Wood et al., 2003), which makes the reduction in the content of these fatty acids interesting in beef. The C16:0 con- centration averaged $25.8 \%$ (Table 5), which was similar to the result $(24.9 \%)$ found in heifers fed with different energy sources in diets based on cottonseed hulls and soybeans by Kazama et al. (2008). Similar values for fatty acids C14:0 (2.52 \%), C16:0 (23.46 \%) and C18:0 (15.44 $\%)$ were reported by Silva et al. (2002).

Although the saturated fat in beef may contribute to the elevation of cholesterol content circulating in humans, fats rich in stearic acid did not show these characteristics. C18:0 is considered to be neutral in the control of plasma cholesterol levels (Scollan et al., 2006). In addition, stearic acid is important in the sensory factors of meat because a greater score was observed by the gourmet panel for cuts of meat with greater concentrations of this fatty acid (Mir et al., 2000).

The concentration of oleic acid (C18:1 C9) had an average value of $38.5 \%$. This value is slightly greater than the values found by Kazama et al. (2008), Fernandes et al. (2009) and Rotta et al. (2009a) at $33.98 \%$, $35.96 \%$ and $36.53 \%$, respectively. The values in this

Table 5 - Composition of fatty acids of the Longissimus muscle samples from the feedlot-finished crossbred heifers receiving different lipid sources.

\begin{tabular}{|c|c|c|c|c|c|c|}
\hline \multirow{3}{*}{ Fatty acid } & \multicolumn{6}{|c|}{ Longissimus Muscle } \\
\hline & \multicolumn{3}{|c|}{ Diet $^{A}$} & \multirow{2}{*}{ SEM $^{B}$} & \multirow{2}{*}{$P$ value } & \multirow{2}{*}{$\mathrm{CV}^{\mathrm{c}}$} \\
\hline & SB & $\mathrm{PF}$ & SO & & & \\
\hline & \multicolumn{3}{|c|}{$\longrightarrow$} & & & \\
\hline C10: 0 (capric) & 0.07 & 0.09 & 0.07 & 0.01 & 0.18 & 33.70 \\
\hline C12: 0 (lauric) & 0.09 & 0.11 & 0.09 & 0.02 & 0.37 & 28.00 \\
\hline C14: 0 (myristic) & 2.99 & 3.37 & 3.09 & 0.11 & 0.34 & 15.10 \\
\hline C14: 1 C9 (myristoleic) & 0.66 & 0.75 & 0.88 & 0.05 & 0.16 & 25.20 \\
\hline C15: 0 (pentatonic) & 0.41 & 0.36 & 0.39 & 0.01 & 0.53 & 17.50 \\
\hline C16: 0 (palmitic) & 25.60 & 26.40 & 25.40 & 0.30 & 0.38 & 5.20 \\
\hline C16: 1 C9 (palmitoleic) & 3.51 & 3.28 & 3.76 & 0.46 & 0.14 & 12.30 \\
\hline C17: 0 (daisy) & 0.87 & 0.88 & 0.88 & 0.10 & 0.98 & 12.00 \\
\hline C18: 0 (stearic) & 14.60 & 15.40 & 13.70 & 0.42 & 0.24 & 12.50 \\
\hline C18: 1 C9 (oleic) & 37.80 & 38.70 & 38.80 & 0.55 & 6.68 & 0.74 \\
\hline 18:2 C9 C12 (linoleic) & $3.84^{\mathrm{a}}$ & $2.33^{\mathrm{b}}$ & $2.90^{\mathrm{ab}}$ & 0.25 & 0.04 & 33.20 \\
\hline 18:3 n3 (linolenic) & $0.21^{\mathrm{a}}$ & $0.12^{\mathrm{b}}$ & $0.17^{\mathrm{ab}}$ & 0.01 & 0.01 & 26.90 \\
\hline 18:2 C9 T 11 (CLA) & 0.49 & 0.50 & 0.56 & 0.04 & 0.73 & 34.90 \\
\hline SFA & 46.20 & 47.90 & 45.10 & 0.52 & 0.07 & 4.44 \\
\hline MUFAE & 46.40 & 47.50 & 49.00 & 0.55 & 0.19 & 5.34 \\
\hline PUFAF & $5.61^{a}$ & $3.36^{\mathrm{b}}$ & $4.25^{\mathrm{ab}}$ & 0.32 & 0.01 & 28.20 \\
\hline$U^{U} A^{G}$ & 52.00 & 50.90 & 53.20 & 0.50 & 0.13 & 4.01 \\
\hline UFA:SFA & 1.13 & 1.06 & 1.18 & 0.02 & 0.09 & 8.45 \\
\hline PUFA:SFA & $0.12^{\mathrm{a}}$ & $0.07^{b}$ & $0.09^{a b}$ & 0.01 & 0.01 & 29.90 \\
\hline Total FA cis $18^{\mathrm{H}}$ & 43.80 & 42.90 & 45.00 & 0.54 & 0.29 & 5.35 \\
\hline Total FA trans $18^{\prime}$ & 5.67 & 5.11 & 4.73 & 0.28 & 0.38 & 24.10 \\
\hline $\mathrm{C} 16 \Delta^{9}$-desaturase & $11.70^{\mathrm{ab}}$ & $11.00^{\mathrm{b}}$ & $12.90^{\mathrm{a}}$ & 0.33 & 0.04 & 11.20 \\
\hline C18 $\Delta^{9}$-desaturase ${ }^{\mathrm{L}}$ & 71.20 & 71.60 & 73.90 & 0.70 & 0.28 & 4.55 \\
\hline
\end{tabular}


study were also slightly greater than those reported by Enser et al. (1998). In this referenced study, they performed a survey to evaluate the composition of the fatty acids of bovine, sheep and pig meat acquired in various supermarkets. They observed that beef had an elevated content of C18:1 C9 (36 \%), and the meat from sheep and pigs had averages of $32.5 \%$ and $32.8 \%$ of C18:1 C9, respectively. However, similar values of oleic acid were found by Felton and Kerley (2004). They evaluated the profile of fatty acids in cattle fed traditional diets with a base of soybean meal and corn meal or diets with high levels of lipids, and they found an average value of 37.7 $\%$ for oleic acid. The increase in the concentration of oleic acid is highly desirable because this fatty acid has hypocholesterolemic properties (Mir et al., 2003).

The concentration of linoleic acids and linolenic acids was higher in the animals fed with soybeans than the concentrations of animals that received protected fat. Linolenic fatty acid is an essential fatty acid, as it is the precursor for the synthesis of many PUFAs /Oda et al., 2004). These authors highlighted that although most PUFAs are not essential, they have an important role in the reduction of blood cholesterol. These results were confirmed by other authors who described a low occurrence of heart disease despite the high consumption of fats in Mediterranean countries where there is a wide use of olive oil and similar products that provide substantial absorption of MUFAs, mainly oleic acid. As a result of this diet rich in olive oil, the decrease in blood cholesterol was shown in comparison to that of diets low in fat (Wood et al., 1999).

The C16 $\Delta^{9}$-desaturase enzyme has greater activity in the Longissimus muscle from the animals fed with soybean oil than the activity of animals fed with protected fat (Table 5). This enzyme is responsible for the desaturation of SFAs with 16 and 18 carbons, converting them into their corresponding MUFAs with a double bond on C9 (Beaulieu et al., 2002).

Production of CLA by $\Delta^{9}$-desaturase is performed by trans-vaccenic acid (C18:1 t11) and is produced by the incomplete biohydrogenation of linoleic and linolenic acids by ruminal bacteria (Fernandes et al., 2009). Often, the biohydrogenation of linoleic fatty acid is not completed. Therefore, significant quantities of conjugated fatty acid and trans-MUFA, such as vaccenic fatty acid, reach the duodenum and are absorbed, ending up in the milk or in the tissue (Metz et al., 2009). This enzyme acts in the epithelium of the intestine and muscle tissue but at a lesser intensity than the enzyme in adipose tissue (Beaulieu et al., 2002). This enzyme's activity may be influenced by breed, age, sex and degree of physiological maturity of the animals. The deposition rate of CLA does not depend on the final quantity of body fat of the animals but, instead, is favoured in conditions where a lower rate of fat deposition occurs (De La Torre et al., 2006).

Dannenberger et al. (2004) observed ten isomers of CLA in beef and noted that the cis-9 trans-11 isomer represented $70 \%$ of the total CLA. They also suggested that this isomer has recognised anticarcinogenic and antiteratogenic effects. They emphasised the importance of the endogenous synthesis of cis- 9 trans-11 CLA by the action of the $\Delta^{9}$-desaturase enzyme. This process occurs from vaccenic acid (C18:1 trans-11), which is an intermediate product formed during the process of ruminal biohydrogenation of linoleic acid. In this study, the average concentration of CLA (18:2 cis-9 trans-11) in the Longissimus muscle was $0.52 \%$, which was a similar value to that found by Fernandes et al. (2009) for Canchim heifers (0.56\%). However, Macedo et al. (2007) and Felton and Kerley (2004) reported values below $0.32 \%$ and $0.12 \%$, respectively.

Trans-fatty acids are unsaturated and, contrary to cis-UFAs, possess double-bonded hydrogen that is available in a transversal form and are the results of ruminal biohydrogenation or industrial processes. Trans-fatty acids are related to harmful effects on human health. Sanhueza et al. (2002) relate the effects of trans-fatty acids to the blood lipids, inhibitory action of liver enzymes, modification of cellular membrane fluidity and arteriogenic potential. However, long chain PUFAs participate in several beneficial metabolic processes for human health (Varela et al., 2004) and that the meat fats from ruminants are natural sources of several of these fatty acids.

The total content of PUFAs and the ratio of PUFAs to SFAs were greater in animals fed with soybeans than that of animals fed with protected fat. An increase in the ratio of PUFAs to SFAs in the human diet is considered a priority for the reduction of plasma cholesterol (Ponnampalam et al., 2001). Silva et al. (2002) reported an average ratio of 0.20 for confined crossbred heifers, which was a greater value than reported in this study. The ratio of PUFAs to SFAs was less than that recommended by the Department of Health of the United Kingdom, which recommends a value of approximately 0.4 , characterising a healthier diet (Wood et al., 2003). Therefore, Jakobsen (1999) suggests a reduction in the ingestion of fats rich in cholesterol and SFAs and an increase in the consumption of MUFAs and PUFAs to reduce the risk of obesity, cancer and cardiovascular diseases.

In the sirloin subcutaneous fat, there was a difference $(p \leq 0.05)$ in the percentage of oleic acids, MUFAs, total cis-fatty acids (C18:0) and total trans-fatty acids (C18:0). There was also a difference $(p \leq 0.05)$ observed in the index of the C16 $\Delta^{9}$-desaturase enzyme. The following measurements were not affected $(p>0.05)$ by the lipid sources: remaining fatty acids, total content of SFAs, PUFAs and UFAs, index of the C18 $\Delta^{9}$-desaturase enzyme, ratio of UFAs to SFAs and ratio of PUFAs to SFAs (Table 6). The diet with soybean oil increased the content of MUFAs, total cis-fatty acids (C18:0) and trans-fatty acids (C18:0) present in subcutaneous fat when compared to the diet with protected fat. The C16 $\Delta^{9}$-desaturase enzyme had higher activity in the subcutaneous fat samples from animals fed with soybean oil and soybeans than from the animals that received protected fat. 
Table 6 - Composition of fatty acids of samples of subcutaneous fat in the sirloin of feedlot-finished crossbred heifers receiving different lipid sources.

\begin{tabular}{|c|c|c|c|c|c|c|}
\hline \multirow{3}{*}{ Fatty acid } & \multicolumn{6}{|c|}{ Subcutaneous fat over the sirloin } \\
\hline & \multicolumn{3}{|c|}{$\operatorname{Diet}^{A}$} & \multirow{2}{*}{$\mathrm{SEM}^{\mathrm{B}}$} & \multirow{2}{*}{$P$ value } & \multirow{2}{*}{ CVc } \\
\hline & SB & $\mathrm{PF}$ & SO & & & \\
\hline & \multicolumn{3}{|c|}{$\%$} & & & \\
\hline C10: 0 (capric) & 0.06 & 0.07 & 0.07 & $<.01$ & 0.23 & 20.00 \\
\hline C12: 0 (lauric) & 0.09 & 0.09 & 0.10 & $<.01$ & 0.93 & 26.00 \\
\hline C14: 0 (myristic) & 3.75 & 3.95 & 3.59 & 0.13 & 0.58 & 16.90 \\
\hline C14: 1 C9 (myristoleic) & 1.14 & 1.05 & 1.33 & 0.08 & 0.34 & 28.60 \\
\hline C15: 0 (pentatonic) & 0.55 & 0.48 & 0.50 & 0.02 & 0.52 & 22.40 \\
\hline C16: 0 (palmitic) & 25.70 & 26.40 & 25.10 & 0.34 & 0.29 & 5.87 \\
\hline C16: 1 C9 (palmitoleic) & 4.29 & 3.54 & 4.40 & 0.17 & 0.07 & 16.40 \\
\hline C17: 0 (daisy) & 0.94 & 0.94 & 0.92 & 0.02 & 0.93 & 10.10 \\
\hline C18: 0 (stearic) & 14.10 & 15.09 & 13.17 & 0.51 & 0.33 & 15.90 \\
\hline C18: 1 C9 (oleic) & $40.20^{\mathrm{ab}}$ & $37.70^{\mathrm{b}}$ & $41.40^{a}$ & 0.61 & 0.03 & 5.96 \\
\hline 18:2 C9 C12 (linoleic) & 1.20 & 0.98 & 0.82 & 0.07 & 0.10 & 30.70 \\
\hline 18:3 n3 (linolenic) & 0.11 & 0.08 & 0.07 & 0.01 & 0.33 & 55.30 \\
\hline 18:2 C9 T 11 (CLA) & 0.87 & 0.72 & 0.87 & 0.05 & 0.49 & 29.30 \\
\hline SFAD & 47.40 & 47.80 & 45.40 & 0.58 & 0.06 & 4.94 \\
\hline MUFAE & $49.10^{\mathrm{ab}}$ & $48.10^{\mathrm{b}}$ & $51.10^{a}$ & 0.52 & 0.04 & 4.13 \\
\hline PUFAF & 2.27 & 1.87 & 1.82 & 0.12 & 0.24 & 26.40 \\
\hline UFA & 51.40 & 49.90 & 52.90 & 0.55 & 0.08 & 4.35 \\
\hline UFA:SFA & 1.09 & 1.03 & 1.17 & 0.02 & 0.06 & 9.01 \\
\hline PUFA:SFA & 0.05 & 0.04 & 0.04 & $<.01$ & 0.28 & 30.90 \\
\hline Total FA cis $18^{\mathrm{H}}$ & $43.60^{\mathrm{ab}}$ & $40.80^{b}$ & $44.50^{a}$ & 0.59 & 0.02 & 5.14 \\
\hline Total FA trans $18^{\prime}$ & $3.07^{b}$ & $5.28^{\mathrm{a}}$ & $3.27^{b}$ & 0.40 & 0.04 & 40.90 \\
\hline C16 $\Delta^{9}$-dessaturase ${ }^{J}$ & $14.30^{\mathrm{a}}$ & $11.80^{\mathrm{b}}$ & $14.90^{a}$ & 0.48 & 0.01 & 12.80 \\
\hline C18 $\Delta^{9}$-desaturase ${ }^{L}$ & 74.10 & 71.40 & 75.90 & 0.85 & 0.09 & 4.74 \\
\hline
\end{tabular}

ASB - diet containing $60 \%$ corn silage and $40 \%$ concentrate with a base of soybeans as the lipid source; PF - diet containing $60 \%$ corn silage and $40 \%$ concentrate with a base of protected fat as the lipid source; SO - diet containing $60 \%$ corn silage and $40 \%$ concentrate with a base of soy oil as the lipid source; ${ }^{B}$ SEM - standard error of mean; ${ }^{~}{ }^{C} V$-coefficient variation (\%); DSFA - saturated fatty acids = C4:0, C6:0 C8:0, C10:0, C12:0, C13:0iso, C13:0ant, C14:0iso, C14:0, C15:0iso, C15:0ant, C14:1c9, C15:0, C16:0iso, C16:0, C17:0iso, C17:0, C18:0, C20:0, C22:0 and C24:0; EMUFA - monounsaturated fatty acids = C16:1c9, C17:1, C18:1t6, C18:1t9, C18:1t10, C18:1t11, C18:1t12, C18:1c9, C18:1c11, C18:1c12, C18:1c13, C18:1t16, C18:1c15, $\mathrm{C} 20: 1, \mathrm{C} 22: 1$ and C24:1; FPUFA - polyunsaturated fatty acids $=\mathrm{C} 18: 2 \mathrm{t} 11 \mathrm{c} 15, \mathrm{C} 18: 2 \mathrm{c} 9 \mathrm{c} 12, \mathrm{C} 18: 3, \mathrm{C} 18: 2 \mathrm{c} 9 \mathrm{t} 11, \mathrm{C} 20: 3, \mathrm{C} 20: 4, \mathrm{C} 22: 2, \mathrm{C} 20: 5, \mathrm{C} 22: 5$ and C22:6; GUFA - unsaturated fatty acids = MUFA and PUFA; HTotal fatty acids cis18 = C18:1c9, C18:1c11, C18:1c12, C18:1c13, C18:1c15, C18:2t11c15 and C18:2c9c12; 'Total fatty acids trans18=C18:1t9, C18:1t10, C18:1t11, C18:1t12, C18:1t16, C18:1t18, C18:2t11c15 and C18:2c9c12; Index of $\Delta^{9}$-desaturase $\mathrm{C} 16=100 *$ (C16:1n-9 / (C16:0 + C16:1n9)); Lndex of $\Delta^{9}$-desaturase C18=100; ${ }^{*}(\mathrm{C} 18: 1 \mathrm{n}-9$ / (C18:0 + C18:1n9)); a,bAverages followed by different lower case letters, in the same line, differ (Tukey's test, $p<0.05$ ).

The values of oleic acid heifers that received a diet with protected fat $(37.66 \%)$ had lower values compared to the heifers that were fed diets with soybean oil (41.42\%). Higher values of oleic acid are desirable for hypocholesterolemic action, with the advantage of not reducing high-density lipoprotein (HDL) cholesterol (good cholesterol) protecting against coronary diseases. Oleic fatty acid is considered to be good for health, and content is positively correlated with the sensory quality of the meat (Melton et al., 1982).

\section{Conclusions}

Diets with soybean grain had greater deposition of linoleic and linolenic acids than diets with fat protected and greater presence of these essential fatty acids are associated to a better composition and meat quality.

\section{Acknowledgements}

To the Fundação de Amparo à Pesquisa do Estado de São Paulo (FAPESP, São Paulo, Brazil) for financial support.

\section{References}

Abularach, M.L.S.; Rocha, C.E.; Felício, P.E. 1998. Quality traits of boneless rib cut ( $L$. dorsi muscle) from Nelore young bulls. Ciência e Tecnologia de Alimentos 18: 205-210 (in Portuguese, with abstract in English).

Association of Official Analytic Chemists International [AOAC]. 1990. Official Methods of Analyses. 15ed. AOAC, Arlington, VA, USA.

Beaulieu, A.D.; Drackley, J.K.; Merchen, N.R. 2002. Concentrations of conjugated linoleic acid (cis-9, trans-11-octadecadienoic acid) are not increased in tissue lipids of cattle fed a high-concentrate diet supplemented with soybean oil. Journal of Animal Science 80: $847-861$. 
Christie, W.W. 1982. A simple procedure for rapid transmethylation of glycerolipids and cholesterol esters. Journal of Lipid Research 23: 1072-1075.

Dannenberger, D.; Nuernberg, G.; Scollan, N.; Schabbel, W.; Steinhart, H.; Ender, K.; Nuernber, G.K. 2004. Effect of diet on the deposition of n-3 fatty acids, conjugated linoleic and C18:1 trans fatty acid isomers in muscle lipids of German Holstein bulls. Journal of Agriculture and Food Chemistry 52: 6607-6615.

De La Torre, A.; Gruffat, D.; Durand, D.; Micol, D.; Peyron, A.; Scislowski, V.; Bauchart, D. 2006. Factors influencing proportion and composition of CLA in beef. Meat Science 73: 258-268.

Enser, M.; Halllet, K.G.; Hewett, B.; Fursey, G.A.J.; Wood, J.D.; Harrington, G. 1998. Fatty acid content and composition of UK beef and lamb muscle in relation to production system and implications for human nutrition. Meat Science 49: 329-341.

Felton, E.E.D.; Kerley, S. 2004. Performance and carcass quality of steers fed different sources of dietary fat. Journal of Animal Science 82: 1794-1805.

Fernandes, A.R.M.; Sampaio, A.A.M.; Henrique, W.; Oliveira, E.A.; Tullio, R.R.; Perecin, D. 2008. Carcass and meat characteristic of cattle receiving differents diets in feedlot. Arquivo Brasileiro de Medicina Veterinária e Zootecnia 60: 139-147 (in Portuguese, with abstract in English).

Fernandes, A.R.M.; Sampaio, A.A.M.; Henrique, W.; Tullio, R.R.; Oliveira, E.A.; Silva, T.M. 2009. Chemical traits and fatty acids composition of beef from young bulls, steers and heifers fed corn silage and concentrate or sugarcane and concentrate with sunflower grains. Revista Brasileira de Zootecnia 38: 705-712 (in Portuguese, with abstract in English).

Fox, D.G.; Sniffen, C.J.; O`Connor, J.D.; Russel, J.B.; Van Soest, P.J. 1992. A net carbohydrate and protein system for evaluating cattle diets. III. Cattle requirements and diets adequacy. Journal of Animal Science 70: 3578-3596.

French, P.; Stanton, C.; Lawless, F.; O'Riordan, E.G.; Monahan, F.J.; Caffrey, P.J.; Moloney, A.P. 2002. Fatty acid composition, including conjugated linoleic acid, of intramuscular fat from steers offered grazed grass, grass silage or concentrate based diets. Journal of Animal Science 78: 2849-2855.

Griinari, J.M.; Dwyer, D.A.; McGuire, M.A.; Bauman, D.E.; Palmquist, D.L.; Nurmela, K.V.V. 1998. Trans-Octadecenoic acids and milk fat depression in lactating dairy cows. Journal of Dairy Science 81: 1251-1261.

Hamm, R. 1960. Biochemistry of meat hydratation. Advances in Food Research 10: 335-443.

Hara, A.; Radin, N.S. 1978. Lipid extraction of tissues with a lowtoxicity solvent. Analytical Biochemistry 90: 420-426.

Jakobsen, K. 1999. Dietary modifications of animal fats: status and future perspectives. Fett Lipid 101: 475-483.

Kazama, R.; Zeoula, L.M.; Prado, I.N.; Silva, D.C.; Ducatti, T.; Matsushita, M. 2008. Quantitative and qualitative carcass characteristics of heifers fed different energy sources on a cottonseed hulls and soybean hulls based die. Revista Brasileira de Zootecnia 37: 350-357 (in Portuguese, with abstract in English).

Koohmaraie, M.; Kent, P.M.; Shackelford, S.D.; Veiseth, E.; Wheeler, T.L. 2002. Meat tenderness and muscle growth: is there any relationship? Meat Science 62: 345-352.
Lanna, D.P.D.; Barioni, L.G.; Boin, C.; Tedeschi, L.O. 1999. RLM 2.0: Feed for Maximum Profit; Version 2.0. RLM, Piracicaba, SP, Brazil. (CD-ROM)

Lawrie, R.A. 2005. Meat Science. 6ed. Artmed, Porto Alegre, RS, Brazil (in Portuguese).

Macedo, L.M.A.M.; Prado, I.M., Ducatti, T.; Prado, J.M., Matsushita, M.; Prado I.N. 2007. Performance, carcass characteristics and chemical composition of nonpregnant or pregnant heifers finished in feedlot. Acta Scientiarum. Animal Sciences 29: 425-432 (in Portuguese, with abstract in English).

Malau-Aduli, A.E.O.; Siebert, B.D.; Bottema, C.D.K.; Pitchford, W.S. 1997. A comparison of the fatty acid composition of triacylglycerols in adipose tissue from Limousin and Jersey cattle. Australian Journal of Agricultural Research 48: 715722 .

Meilgaard, D.; Civille, G.V.; Can, B.T. 1999. Sensory Evaluation Techniques. Boca Raton: CRC Press, FL, USA.

Melton, S.L.; Amiri, M.; Davis, G.W.; Backus, W.R. 1982. Flavor and chemical characteristics of ground beef form grass-, foragegrain- and grain-finished steers. Journal of Animal Science 55: 77-87.

Metz, P.A.M.; Menezes, L.F.G.; Santos, A.P.; Brondani, I.L.; Restle, J.; Lanna, D.P.D., 2009. Fatty acids profile in meat of steers from different ages and genetic groups finished in feedlot. Revista Brasileira de Zootecnia 38: 523-531 (in Portuguese, with abstract in English).

Mir, P.S.; Ivan, M.; He, M.L.; Pink, B.; Okine, E.; Goonewardene, L.; McAllister, T.A.; Weselake, R.; Mir, Z. 2003. Dietary manipulation to increase conjugated linoleic acids ond other desirable fatthy acids in beef: a review. Canadian Journal of Animal Science 3: 673-685.

Mir, Z.; Paterson, L.J.; Mir, P.S. 2000. Fatty acid composition and linoleic acid content of intramuscular fat in crossbred cattle with and without Wagyu genetics fed a barley based diet. Canadian Journal of Animal Science 80: 195-197.

Oda, S.N.I.; Bressan, M.C.; Cardoso, M.G.; Freitas, R.T.F.; Miguel, G.Z.; Faria, P.B., Vieira, J.O.; Pisa, A.C.C.; Savian, T.V. 2004. Effect of two slaughter methods and sex on proximate composition, cholesterol content and fatty acids profile of capybara meat (Hydrochaeris Hydrochaeris L. 1766). Ciência e Tecnologia de Alimentação 24: 236-242 (in Portuguese, with abstract in English).

Oliveira, E.A.; Sampaio, A.A.M.; Fernandes, A.R.M.; Henrique, W.; Oliveira, R.V.; Ribeiro, G.M. 2009. Performance and carcass traits of Nellore and Canchim young bulls finished in a feedlot system, receiving diets with sugarcane and two concentrate levels. Revista Brasileira de Zootecnia 38: 24652472 (in Portuguese, with abstract in English).

Pereira, L.P.; Restle, J.; Brondani, I.L.; Alves Filho, D.C.; Silva, J.H.S.; Muehlmann, L.D. 2000. Growth of beef cattle from different genetic groups of charolais $x$ nellore intact or castrated at eight months. Ciência Rural 30: 1033-1039 (in Portuguese, with abstract in English).

Ponnampalam, E.N.; Sinclair, A.J.; Egan, A.R.; Blakeley, S.J.; Leury, B. 2001. Effect of diets containing n-3 fatty acids on muscle long-chain n-3 fatty acid content in lambs fed low- and medium-quality roughage diets. Journal of Animal Science 79: 698-706. 
Restle, J.; Cerdótes, L.; Vaz, F.N.; Brondani, I.L. 2001. Carcass and meat characteristics of charolais and $3 / 4$ charolais $1 / 4$ nellore cull heifers, finished in feedlot. Revista Brasileira de Zootecnia 30: 1065-1075 (in Portuguese, with abstract in English).

Rotta, P.P.; Prado, I.N.; Prado, R.M.; Molleta, J.L.; Silva, R.R.; Perotto, D. 2009a. Carcass characteristics and chemical composition of the Longissimus muscle of Nellore, Caracu and Holstein-friesian bulls finished in a feedlot. Asian-Australasian Journal of Animal Science 22: 598-604.

Rotta, P.P.; Prado, R.M.; Prado, I.N.; Valero, M.V.; Visentainer, J.V.; Silva, R.R. 2009b. The effects of genetic groups, nutrition, finishing systems and gender of Brazilian cattle on carcass characteristics and beef composition and appearance: a review. Asian-Australasian Journal of Animal Science 22: 1718-1734.

Sanhueza, J.; Nieto, S.; Valenzuela, A. 2002. Conjugated linoleic acid: a trans isomer fatty acid potentially beneficial. Revista Chilena de Nutrición 29: 98-105 (in Spanish, with abstract in English).

SAS Institute. 1997. Statistical Analysis System: User's Guide; Version 6.08. 4ed. SAS Institute, Cary, NC, USA.

Scollan, N.; Hocqette, J.F.; Nuernberg, K.; Dannenberger, D.; Richardson, I.; Moloney, A. 2006. Innovations in beef production systems that enhance the nutritional and health value of beef lipids and their relationship with meat quality. Meat Science 74: 17-33.

Silva, J.A.; Patarata, L.; Martins, C. 1999. Influence of ultimate $\mathrm{pH}$ on bovine meat tenderness during ageing. Meat Science 52: 453-459.
Silva, R.G.; Prado, I.N.; Matsushita, M.; Souza, N.E. 2002. Dietary effects on muscle fatty acids composition of finish heifers. Pesquisa Agropecuária Brasileira 37: 95-101.

Stolowski, G.D.; Baird, B.E.; Miller, R.K.; Savell, J.W.; Sams, A.R.; Taylor, J.F.; Sanders, J.O.; Smith, B. 2006. Factors influencing the variation in tenderness of seven major beef muscles from three Angus and Brahman breed crosses. Meat Science 73: 475-483.

Van Soest, P.J.; Robertson, J.B.; Lewis, B.A. 1991. Methods for dietary fiber, neutral detergent fiber, and nonstarch polysaccharides in relation to animal nutrition. Journal of Dairy Science 74: 3583-3597.

Varela, A.; Oliete, B.; Moreno, T.; Portela, C.; Monserrrat, L.; Carballo, J.A.; Sánchez, L. 2004. Effect of pasture finishing on the meat characteristics and intramuscular fatty acid profile of steers of the Rubia Gallega breed. Meat Science 67: 515-522.

Webb, E.C. 2006. Manipulating beef quality through feeding. South African Journal of Animal Science 7: 5-15.

Wood, J.D.; Enser, M.; Fisher, A.V.; Nute, G.R.; Richardson, R.I.; Sheard, P.R. 1999. Manipulating meat quality and composition. Proceedings of the Nutrition Society 58: 363-370.

Wood, J.D.; Richardson, R.I.; Nute, G.R.; Fisher, A.V.; Campo, M.M.; Kasapidou, E.; Sheard, P.R.; Enser, M. 2003. Effects of fatty acids on meat quality: a review. Meat Science 66: 21-32. 